\title{
Compliance with Labour Rights and International Labour Standards: Implications for Workplace Productivity and Competitiveness
}

\author{
Dr. Michael O. Samuel \\ School of Economic and Business Sciences \\ University of the Witwatersrand, Johannesburg, South Africa \\ Email: Olorunjuwon.samuel@wits.ac.za
}

\section{Doi:10.5901/mjss.2014.v5n9p89}

\section{Abstract}

\begin{abstract}
The common perception, particularly among employers of labour is that enforcement or implementation of enhanced labour standards would negatively impact on overhead costs thereby impeding the organisation's competitive advantage through price mechanisms at both national and global marketplace. The purpose of this paper is to provide an analysis and draw inherent relationships between enforcement of labour standards by organisations and possible implications on workplace productivity and overall organisational efficiency, competitiveness and survival. Theorists of firm's wage efficiency argue that implementation of enhanced labour standards will most certainly increase overhead costs and push up prices thereby disadvantaging the firm's ability from competing favourably with other firm's operating in territories where labour standards are not observed. However, comparative cost-benefit analysis of implementing labour standards by this paper suggests that organisations indeed benefit significantly by enforcing labour standards as this would translate to higher productivity and enhanced organisational competitiveness and survival as workers experience job satisfaction, safe and healthy working conditions and environment which reduces rate of industrial accidents, medical costs and sick leaves. Furthermore, employers benefit from implementing enhanced labour standards through low employee turnover rate and improved cooperation and understanding between workers and their employers resulting in a stable and positive labour relations environment that is devoid of unplanned work stoppages due to industrial actions and loss of production.
\end{abstract}

Keywords: core labour rights; international labour standards; productivity; competitiveness; conflicting necessities; commonality

\section{Introduction}

The commonality between labour (worker) and capital (employer) is the continued existence of the business for the mutual benefits of both parties through its ability to favourably compete both locally and in the global marketplace. For the business to continue to operate into the future, the employer depends on the services and output (productivity) provided by the worker, while the latter equally depend on the rewards derived from employment for his own socio-economic wellbeing. Most often however, this symbiotic relationship is often characterised by the conflicting interests and behaviour of both parties; and this, sometimes threatens the very existence of the object of common interest (the business). While labour (through its representatives - unions) continually agitate for improved and increased economic and social benefits (mostly wages) that are considered essential for quality living and well-being of its members, the employer (represented by management), on the other hand, considers it imperative to minimise workers' demand in order to realise predetermined organisational goal - the bottom-line of which, in most cases, is profit maximisation and creation of wealth for its shareholders. This conflict of necessities thus presents a complex platform upon which relationships are built in the workplaces.

\section{Labour Rights}

The Bill of Rights as enshrined in Chapter 2 of the Constitution of the Republic of South Africa (1996) protects the fundamental rights of every citizens of South Africa. Specifically, various International Labour Organisations (ILO) Conventions stipulate certain rights that workers are entitled to (hereinafter refer to as Labour Rights). Similarly, various countries enacts statutes that specifically regulate the relationship between employers and employees, and these statutes also contain certain rights that workers are entitled to and which must be protected by both the state and employers. Such statute in South Africa is the Labour Relations Act no. 66 of 1995 (LRA, 1995). This essay will be articulated within the context of the implementation of labour rights and the International Labour Standards (ILS) 
(International Labour Organisation, 2004, p. 143) in relation to workplace productivity and competitiveness.

The Wikipedia described the rights of workers (labour rights) as a collection of rights that are recognised by the law which exist in the workplaces and regulate the relationships between employees and their employers. These rights are, in most cases usually contained in labour and employment laws, and in most cases generally involve wage negotiation, workers' benefits and working conditions (Mantouvalou, 2013, p. 3). One of the most central of these rights is the workers' right to form and belong to labour unions thus enabling workers to collectively negotiate their wages and other conditions of employment through their union representatives in order not to be exploited by employers (Mantouvalou, 2003). Mantoucalou further contend that labour rights are essentially derived from the role of being a worker, thus translating labour rights into basic human rights. Some of these rights are exercised individually and or collectively and include "a right to work in a job freely chosen; a right to fair working conditions, which may encompass issues as diverse as a just wage or protection of privacy; a right to be protected from arbitrary and unjustified dismissal; a right to belong to, and be represented by a trade union, a right to strike" (Mantouvalou, 3013, p. 3). A further analysis of these rights have far reaching implications on workforce productivity since most, if not all of these rights have financial implications for the employer. For example, a right to fair working conditions and extended benefits and allowances will translate into increased expenditure on the part of the employer and this will directly impact on overall profit earnings. Similarly, the rights to join labour unions and to strike will have profound impact on employee productivity as a huge amount of working hours could be lost to strike actions. Workers have over time often relied essentially on this right in order to compel employers to accede to their (workers) demands, and this has yielded positive results in most cases, but resulted in substantial increase in overhead costs for the employers. This was the case in the prolonged labour unrest at Anglo American Platinum Company (South Africa) which resulted in a net loss of ZAR6.68 billion in 2012, compared with a net profit of ZAR3.59 billion the previous year (2011) after operations were disrupted by several weeks of violent strikes by mineworkers (ADVFN, 2012).

\section{Core Labour Standards}

Core Labour Standards are identified by the International Labour Organisation (ILO) in the 'Declaration of the Fundamental Principles and Rights at Work' (ILO, 2006). Core labour standards are generally considered to be of particular importance (Organisation for Economic Development, 1996) and are universally applicable, notwithstanding the level of development or cultural values of a country, or whether the particular convention have been ratified by the country. They are universal because they are intended to provide a benchmarking mechanism for the treatment of workers in all countries around the world rather than an individual country ((Charnovitz, 1987). These standards are generally expressed in descriptive terms without any particular numerical prescription as to the number of hours a worker must achieve, national minimum wage or health and safety standards (ILO, 2006). Furthermore, core labour standards are not intended to provide a minimum level of standards that employers can implement in the workplace and do not undermine the comparative advantage that developing countries may hold (Charnovitz, 1987). The Core Labour Standards as contextualised by the ILO are described below (Palley, 2002):

1. Freedom of Association - The ILO Freedom of Association and Protection of the Right to Organise Convention (No. 87) establishes the right of workers to form and join organisations, including unions, of their own choosing. Governments may not dictate the form, affiliations, or internal operations of such organisations and may not deny authorisation to nor suspend such organisations. Effective Recognition of the Right to Collective Bargaining - The Right to Organise and Collective Bargaining Convention (No. 98) protects unions from outside interference. Employers may not discriminate against workers who join organisations of their own choosing, nor may they pay for and establish their own woekers' organisations. The state must establish legal mechanisms to prevent this interference. The government must also promote voluntary collective bargaining between workers' organisations and their employers.

2. The Elimination of All Forms of Forced or Compulsory Labour - The Forced Labour Convention (No. 29) and the Abolition of Forced Labour Convention (No. 105) require governments to suppress all forms of forced and compulsory labour in their territories. Forced labour is any form of labour which a worker performs under threat of penalty rather than voluntary. Though there are very limited exceptions for the military and national emergencies, government prohibitions on forced labour must be comprehensive.

3. The Effective Abolition of Child Labour - The Minimum Age Convention (No. 138) sets a baseline minimum working age of fifteen. If a country is insufficiently developed, or if only light work is involved, the minimum age can be lower; conversely, for hazardous occupations the minimum age is eighteen. States must adopt and pursue national policies that effectively end child labour and allow children to fully develop both physically and 
mentally.

4. The Elimination of Discrimination in Respect of Employment and Occupation - the Discrimination Convention (No. 111) requires governments to establish national policies that eliminate discrimination on the basis of race, colour, sex, religion, political opinion, and national or social origin. Discrimination includes unequal access to employment and training as well as disparate working conditions, and the national policy must address both unequal opportunities and treatment. The Equal Remuneration Convention (No. 100) completes this standard by establishing the right of men and women to equal pay for work of equal value.

Even though only a handful of ILO member countries have ratified all of these conventions due to domestic constraints, they are nonetheless obliged to recognise them since the core labour standards form a part of customary international laws (Palley, 2002). For example, the ILO Conventions dealing with Core Labour Standards have been ratified by well over 100 countries (Brown, 2001, p.89). Similarly, the 1 LO Declaration on Fundamental Principles at Work is binding on all the 175 ILO members; and it states inter-alia:

...all Members, even if they have not ratified the Conventions in question, have an obligation arising from the very fact of membership in the Organisation, to respect, to promote and realise, in good faith and in accordance with the Constitution, the Principles concerning the fundamental rights which are the subject of those Conventions..." (Brown, 2001, p.93).

There are many other issues outside of the core standards that some countries have implemented to also compliment the core standards. In the United Kingdom (UK) for example, employee rights includes the right to employment particulars, a pay statement that shows all entitlements paid such as basic cash pay, overtime pay, etc. and deductions made by the employer such as tax, medical aids, retirement benefit contributions, a disciplinary process that allowed an employee to be represented by a shop steward or legal representative, lunch hours, rest breaks, paid holidays and more (www.citation.co.uk/employment-law). Similarly in South Africa, the Basic Conditions of Employment Act 75 of 1997 provides for family leaves such as maternity and family responsibilities leave for qualified employees and these leave periods may not be reduced by a collective agreement (Basic Conditions of Employment Act, 1997).

\section{International Labour Standards (ILS)}

International Labour Standards emanates from a growing necessity for the ILO to provide a humane working environment and enhanced conditions of work for workers globally (Report of the World Commission on the Social Dimension of Globalization, ILO, 2004, p. 143). The report include issues such as maternity leave for women with job security while on such leave, ensure safe working conditions for workers in volatile economic sectors such as mining and agriculture. International labour standards generally are a set of rules agreed upon by international actors (governments, employers, workers) under the auspices of the ILO to protect basic worker rights, enhance workers' job security, and improve their terms of employment on a global scale (ILO, 2009). The intent of such standards, then, is to establish a worldwide minimum level of protection from inhumane labour practices through the adoption and implementation of these measures (Brown, Alan, \& Deardorff, 1996). One of the motivations for the necessities of ILS also is to ensure that countries that do not adhere to the use of these standards do not gain competitive advantage over those who do in international trade. For example, goods and services produced by a country using forced labour (such as prisoners, slavery) or exploit labour processes by subjecting workers to unregulated working hours, compromised safety requirements in the workplaces or paying below living wages could afford to manipulate commodity prices through cheap exports to countries that implement international standards thus giving the former a competitive trade advantage in the global market. Thus, the ILO Convention on ILS states that

an international legal framework on social standards ensures a level playing field in the global economy. It helps governments and employers to avoid the temptation of lowering labour standards in the belief that this could give them a greater competitive advantage in international trade....because international Labour Standards are minimum standards adopted by governments and the social partners, it is in everyone's interest to see these rules applied across board, so that those who do not put them into practice do not undermine the efforts of those who do (Baccini \& KoenigArchibugi, 2012, p.2-3).

The primary international agency charged with developing working standards is the International Labour Organisation (ILO). Established in 1919, the ILO advocates international standards as essential for creating and maintaining opportunities for working class people across the world and ensuring that all workers obtain a decent and 
productive working environment that is dignify, secure, free and promote equity among genders (Baccini \& KoenigArchibugi, 2012, p.2-3). Baccini and colleague further state that it is part of the intentions of the ILO to install ILS as part of a global economic system that enable workers to sufficiently benefit from the global economic growth which they have created through their labour.

Although the existence of international labour standards does not necessarily imply implementation or enforcement by governments, labour laws in most countries have adopted the guidelines provided by the ILO in formulating their labour regulations (Günseli \& Rodgers, 2006). For example, in South Africa, most provisions stipulated in the Basic Conditions of Employment Act no. 75 of 1997 and the Labour Relations Act no. 66 of 1995 relating to the employment of underage persons, conditions of employment generally and regulating relations between workers and employers were derived directly from the relevant ILO Conventions.

Implementation of international labour standards is neither limited to the ILO nor is it constrained to the legislative model that the ILO represents. It is obligatory on states that have ratified ILO Conventions to report the level of their compliance on a regular basis to the ILO office, while the ILO Article 26 provides that another member of the ILO can report to the organisation if a state fails to comply with any Convention which they have ratified ((Brown, 2001, p.93). Other alternatives include direct trade sanctions, multilateral enforcement, and voluntary standards. In addition to controversies that arise over each of these models, greater issues have also been raised concerning the debate over the need for international labour standards themselves. However, while critics have arisen, the international community has largely come to a consensus in favour of basic protection of the world's labour force from inhumane practices (Maskus, 1999). This was further demonstrated by the ILO which states that "the rules of the global economy should be aimed at improving the rights, livelihoods, security, and opportunities of people, families and communities around the world" (ILO Report, 2004, p. 143).

Gunderson (2005) notes that working on the other direction of the necessities for labour standards however is an equally compelling set of forces trying to restrict the use of labour standards. First and foremost, Gunderson noted the concern that productivity will be affected as a result of the costs associated with implementing labour standards, and this is more so given that modern economic system, which is largely knowledge based requires some level of flexibility in order to be efficient and remain competitive in the global market. This issue is particularly important when competing against countries with few labour standards. Another concern identified by Gunderson is the possibility of joblessness as higher costs associated with the implementation of labour standards may price some jobs out of the market, thus raising the issue of whether it is better to have jobs that are not fully protected, or to have no jobs at all.

Gunderson further argued that, while there is an increased need or demand for the protection of labour standards, there is also a reduced ability of employers and governments to supply or provide such labour standards. While it is possible for public sector organisations to absorb costs of implementing labour standards because they are service oriented and funded by the government, many private sector employers are less able to pass any cost increase associated with labour standards to consumers since the prices of goods and services are increasingly set on world markets (Gunderson, 2005). Even if private sector organisations wanted to provide more costly labour standards for equity oriented reasons to their workers, they could, according to Gunderson, risk their survival as a result of their operating environment which is highly competitive. The impact of increased overhead costs will be more challenging especially to small and medium size (SMEs) businesses which are known to have provided huge employment opportunities globally.

Regarding legislative option, Gunderson submits that

\begin{abstract}
Governments are also under similar pressures that make it difficult for them to provide legislated labour standards. In a world of mobile capital (both financial and physical capital) investment will gravitate towards countries and jurisdictions within countries that have fewer costly regulations, including labour regulations. In such a world, business has a more credible threat of locating its plants and new investments into jurisdictions that are more "open for business". Governments are under increased pressure to compete for such business investment and the jobs associated with that investment.
\end{abstract}

\title{
5. Integrating Economic Theories with Labour Standards and Employee Productivity
}

Most often, employers and countries perceive international labour standards as entailing significant costs and thus hindering economic development. A growing body of research indicates, however, that compliance with international labour standards often accompanies improvements in productivity and economic performance. A world bank report (World Bank, 2005) suggest that a higher wage and working time standards and respect for equality can translate into better and more satisfied workers and lower turnover of staff. High rate of employee turnover, apart from the financial 
costs, results in temporary loss of productivity and inhibit competitiveness (Porter, 2003). According to Porter, organisations derive a wide range of economic benefits from implementing labour standards. For example, investment in vocational training can result in a better-trained workforce and higher employment levels. Similarly, Porter argues that safety standards can reduce costly accidents and health care fees; employment protection can encourage workers to take risks and to innovate, social protection such as unemployment schemes and active labour market policies can facilitate labour market flexibility thus making economic liberalisation and privatisation sustainable and more acceptable to the public. Furthermore, freedom of association and collective bargaining with labour unions can lead to better labourmanagement consultation and cooperation (Porter, 2003), thereby reducing the frequency of costly labour conflicts and strikes thereby enhancing social stability in the workplace.

\title{
6. The Efficiency Wage Theory and Workplace Productivity
}

The efficiency wage theory in its simplification provides support for the ILS by suggesting that increasing wages can, in certain circumstances, increase labour productivity because workers will show greater loyalty and commitment when employers improve conditions of work by implementing ILS (Ferguson, 1994). Ferguson contends that if low paid workers get a pay rise, they may feel greater loyalty to the company and fear there is more to lose from being sacked. Therefore, the higher wage may inspire increased productivity. Labour economists have, however questioned the extent to which the efficiency wage theory is practicable, but they agreed that it is theoretically possible. For example, Domingo (Internet) argue that rising real wages do not necessarily lead to a loss of competitiveness provided there is a corresponding rise in labour productivity. In the ever increasing world of technology, improved technology has enabled a greater output per worker thus translating to higher wages without a loss of competitiveness. In other words, there is increase in labour costs, but workers on the other hand produce a greater output, therefore the cost per output stays the same or even increases. Citing the German model, Rene Domingo states that German wages have increased since the 1950s quite dramatically, but they are amongst the most competitive countries in the world because of high labour productivity. Domingo notes that the real problem lies in increasing wages without any corresponding increase in productivity; this could potentially account for a loss of competitiveness.

Domingo extends his argument further by stating that employers are often apprehensive whenever governments contemplate minimum wage increase, or during wage bargaining with labour unions because of the implication of such wage raises on overhead costs which they (employers) may not be able to pass on to consumers for fear of losing competitive advantage. In such circumstance, the tendency is for employers to result to retrenching workers, reducing marketing and advertising budget, downsize operations, etc. in order to offset the costs of wage increase (Domingo, Internet). These measures, according to Domingo, are nothing but easy ways of avoiding a creative solution to the problem which could compromise the continued survival of the company since they threatened various stakeholders of the organisation such the employees, customers, and suppliers. Domingo concluded that any wage hike, present and future, can be more than offset by increasing the productivity of the present workforce rather than management embarking on budget cuts which could be counter-productive.

The core argument of the wage efficiency theory is that wages will go up whether we like it or not, what business managers should bother themselves about really is low labour cost, which can be achieved through increased productivity. Asian countries such as Japan, Korea and Taiwan, are known for producing cheaper goods even though their wages are much higher than less developed Asian countries (Gunderson, 2005). This, according to Gunderson is possible as a result of motivating their workforce to achieve high productivity coupled with operational efficiency.

Going by the evidence provided by the body of literature reviewed so far in this article, there appear to be a significant support for the relationship between the implementation of labour standards and improvement in workplace productivity thus leading to organisational competitiveness. Gunderson concluded by stating that:

\begin{abstract}
Most of the new workplace practices such as the job design features associated with high performance work systems, employee involvement, pay for performance, compressed work weeks and flexitime, work sharing and job sharing, multi-skill training, diversity management, and workplace well-being programmes had positive effects on employees (satisfaction, tardiness, absenteeism, commitment, motivation, effort, performance) which in turn positively affected firm performance, productivity and competitiveness.
\end{abstract}

\section{Conclusions}

The context of this article is derived from the major contentions in labour rights and labour standards literature as to 
whether adherence to international labour standards by organisations do indeed enhance or inhibit productivity, competitiveness and the ability of a business to grow or survive. Arguments have been provided to demonstrate; on the one hand that adoption and enforcement of labour rights and labour standards are indeed imperative for the enhancement of workforce productivity and competitiveness of any business. On the opposing side too, documented evidence drawn from conventional economic arguments has also been provided to suggest that enforcement of labour rights and labour standards respectively do indeed inhibit productivity and competitiveness to a large extent by increasing costs and reducing the flexibility of labour markets.

Current trend in the mining industry in South Africa is very instructive. The mining sector is very crucial to the South African economy in terms of its overall contribution to the Gross Domestic Products (GDP), revenue to the national treasury (corporate tax) and employment (providing about 500,000 jobs). However, the sector has been historically characterised by protracted and prolonged strike actions. Operations in the sector is currently been threatened by a looming strike over the recent decision by management of many of the mining companies to lay off thousands of workers due to operational restructuring. The mining sector witnessed series of wildcat strikes by mineworkers in the mid-2012 and other work stoppages which crippled production with the resultant loss of productivity and profits (Azikiwe, 2013). Recently, the National Union of Mineworkers (NUM), an affiliate of the Congress of South African Trade Unions (COSATU) proposed a wage demand of 60 percent pay increase to the Chamber of Mines, while its counterpart, the Association of Mineworkers and Construction Union (AMCU) proposed an outright 100 percent salary increase for newly employed Rock Drillers (Mail \& Guardian, 2013). The Chamber has reacted with shock over this demand and financial consultants have claimed that this escalating tension between the mining unions and the owners has deepened the already unstable situation involving the South African economy. "The union demands that surface workers should receive a minimum amount of R7000 (\$750) and underground and opencast workers minimum should be set at R8000 (\$850) per month. For all other categories, the NUM has put a demand of 15 per cent. Furthermore, the union demands that Rockdrill Operators job categories be rolled up to category 8 whilst other categories are rolled up to category 7 (Gross, 2013).

The situation has raised a lot of concerns in government circles while analysts posit that the escalating conflict between labour and management in South Africa is making the system vulnerable (Stoddard, 2013). Financial analysts noted with grave concerns the unrealistic nature of the unions demand in the face of dwindling commodity prices in the international market and the continued fragility of the South African economy (Reuters, 2013). The emerging situation, if not well managed, could lead to other protracted work stoppages reminiscent of the 2012 industrial unrests. What is uncertain however is the ability of management to increase productivity at the level of wage increase in order to offset the costs of labour as proposed by the wage efficiency theorists.

The most visible and most contentious labour rights and labour standard issues include minimum wages, paid leave and holidays, industrial actions, equal wages for equal work, employee safety and health, termination, severance pay and unjust dismissals. All of these issues either directly or indirectly inhibit productivity or constitute direct expense on profitability and this will be reasonably resisted by the employer, but vigorously pursued by workers. On a careful analysis however, enhancement of these workplace issues through the recognition and adoption of labour rights and labour standards by employers may have positive effects on productivity and competitiveness. To the extent that labour standards have offsetting benefits to organisations or indeed stimulate favourable working environment and advance employees' job satisfaction, then the complexity of conflicting necessities becomes a win-win outcome for both labour and capital.

\section{References}

Azikiwe, A. (2013). South African Mineworkers Union Demands 60 Percent Pay Increase". Global Research, May $20,2013$. Available@http://www.globalresearch.ca/south-african-mineworkers-union-demands-60-percent-pay-increase/5335854. Accessed 25 May 2013.

Baccini, L., \& Koenig-Archibugi, M. (2012). Why do states commit to International Labour Standards? The importance of "rivalry" and "friendship". Political Science and Political Economy working paper, Department of Government, London School of Economics, No.1/2011, pp.2-3.

Brown, D.K. (2001). Labour Standards: Where do they belong on the international trade agenda? Journal of Economic Perspectives, 15(3), 89-112

Brown,, D.K., Deardorff, A.V., \& Stern, R.B. (1996). International Labor Standards and Trade: A Theoretical Analysis", Fair trade and harmonization: Prerequisites for free trade? Pp. 227-272.Cambridge, MA: MIT Press.

Charnovitz, S. (1987). The influence of International Labour Standards on the world trading regime: A historical overview. International Labour Review, 126(5), September-October, 1987.

Ferguson, W.D. (1994). Union bargaining power in an efficiency wage environment. Eastern Economic Journal, 20(4), 387-401. 
Gross, C. (2013). South Africa's National Union of Mineworkers Seeking Pay Increases of Up to 60\% from Gold, Coal Producers. Available@: http://www.benzinga.com/news/13/05/3602758/south-africas-national-union-of-mineworkers-seeking-pay-increasesof-up-to-60-fro\#ixzz2UlzZMGqA. Retrieved 25 May 2013

Gunderson, M. (2005). Social economic impact of labour standards. A report prepared for the Federal Labour Standard Review Commission in Canada.

Gunderson, M. (1998). Harmonization of Labor Policies Under Trade Liberalization. Relations Industrielles, 52, $24-52$.

Günseli, B., \& Rodgers, Y. (2006). Asia's race to capture post-MFA markets: a snapshot of labor standards, compliance, and impacts on competitiveness. Asian Development Review, 23(1), 55-86.

International Labour Organisation (2006,). Core Labour Standards Handbook, Manilla http://www.adb.org/Documents/Handbooks/CoreLabor-Standards/default.asp. Accessed 23 May, 2013.

International Labour Organisation (2004). A fair globalization: creating opportunities for all. Report of the World Commission on the Social Dimension of Globalisation:Geneva, 143.

Mail\&Guardian (Online). Double Miners' pay: Demands AMCU. 25 June 2013.

Mantouvalou, V. (2013). In "Labour Rights in the European Convention on Human Rights: An Intellectual Justification for an Integrated Approach to Interpretation". Human Rights Law Review, Advance Access Available @www.oxfordjournals.org. Retrieved 29 June 2013.

Maskus, K.E. (1999). Should core labor standards be imposed through international trade policy? The World Bank: The Policy Working Paper Series 1 (1999), Accessed March 20, 2011.

Organisation for Economic Cooperation and Development (1996). Trade, Employment and Labour Standards: A Study of Core Workers' Rights and International Trade. Available http://www.unglobalcompact.org/AboutTheGC/TheTenPrinciples/labourStandards.html. Accessed 23 May, 2013.

Palley, T.I. (2002). The Child Labour Problem and the need for international labour standards. Journal of Economic Issues, $36(3), 5$.

Porter, L.W. (2003). In organisational, work and personal factors in employee turnover and absenteeism. Psychological Bulletin, 80(3), 151-176.

Republic of South Africa (1996). The Constitution of the Republic of South Africa Act 108 of 1996.Cape Town and Pretoria: Government Printer.

Republic of South Africa (1995). The Labour Relations Act 66. Cape Town and Pretoria: Government Printer

Republic of South Africa (1997. The Basic Conditions of Employment Act 75 of 1997. Cape Town and Pretoria: Government Printer.

Stoddard, E.D. (2013). Exclusive -S.Africa's NUM seeks 15-60 pct wage hikes from gold, coal producers. Available @ http://www.reuters.com/article/2013/05/19/safrica-union-demands-idUSL6N0E008M20130519. Accessed 23 September 2013.

World Bank: World Development Report (2005). A better investment climate for everyone (Washington, DC, 2005), pp. 136-156.

Internet sources

ADVFN (2013). Anglo American to Invest $\$ 11.3$ Billion in South African Platinum Business. Available http://www.advfn.com/nyse /StockNews.asp?stocknews=AU\&article=56140644. Retrieved 13 May 2013.

Domingo, R.T. 'higher wages do not mean higher labour costs'. Available @ http://www.rtdonline.com/BMA/MM/4.html. Retrieved 12 March 2013

Introduction to International Labour Standards. Available@http://www.ilo.org/global/standards/introduction-to-international-labourstandards/international-labour-standards-creation/lang--en/index.htm. Accessed 13 April 2013.

Main mining union NUM seeks wage hikes of up to 60 pct, Reuters, May 17, 2013.

Rules of the game: A brief introduction to International Labour Standards". Revised Edition, 2009. Published by the International Labour Organisation Office, Geneva. Available@www.ilo.org/wcmsp5. Accessed 1 July, 2013.

The benefits of International Labour Standards. Available @ http://www.ilo.org/global/standards/introduction-to-international-labourstandards/the-benefits-of-international-labour-standards/lang--en/index.htm. Accessed 23 May 2023.

The Link Between ILS and Productivity and Competitiveness', available @ http://www.ilocarib.org.tt/Promalco_tool/productivitytools/manual. Accessed 17 May 2013.

Wikipedia, the free encyclopedia. Available @https://en.wikipedia.org/wiki/Labor rights. Accessed 15 May 2013. 